AWEJ for Translation \& Literary Studies, Volume 5, Number4. October 2021

Pp. 162-171 DOI: http://dx.doi.org/10.24093/awejtls/vol5no4.12

\title{
Translating Imperative Sentences from English into Indonesian: COVID-19 Outbreak Text
}

\author{
Milisi Sembiring \\ Department of English Language and Literature \\ Universitas Methodist Indonesia, Medan, Indonesia \\ Corresponding Author: milisi_sembiring@yahoo.com \\ Risnawaty \\ Indonesian Education Study Program, Postgraduate Program \\ Universitas Muslim Nusantara Al-Washliyah, Medan, Indonesia \\ Roswani Siregar \\ Department of Economics \\ Universitas Al-Azhar, Medan, Indonesia \\ Yulia Arfanti \\ Indonesian Education Study Program, Postgraduate Program \\ Universitas Muslim Nusantara Al-Washliyah, Medan, Indonesia \\ Ceisy Nita Wuntu \\ English Education Study Program, Postgraduate Program \\ Universitas Negeri Manado, Indonesia
}

Received: 9/11/2021

Accepted: 10/18/2021 Published: 10/29/2021

\begin{abstract}
The imperative sentences in the source language are categorized as imperative instructions. World health organization instructs the general population not to over-take information when reading or searching for information about Corona Virus Disease 2019 because it affects our mentality. It also instructs to avoid using unhelpful coping strategies. The imperative structure rules for English and Indonesian are different. This paper aims to explore the translation techniques used in translating imperative sentences in the 'Mental health and psychosocial considerations during the COVID-19 outbreak' text into Indonesian. The authors use Molina and Albir's (2002) translation techniques. Data collection is done by taking twenty-three the imperatives in the source language of thirty imperative sentences in the text. The imperative sentences in the SL which have infinitive verbs without to are followed by a noun, verb-ing, past participle, adjective, and $2^{\text {nd }}$ person reflexive pronoun. It is found the suffix -lah to emphasize the verb in the TL. Twenty-two data consist of positive imperative sentences and one negative imperative sentence. The results show that from the twenty-three data, the authors found that there were six translation techniques used by the authors as the translators, namely: compensation, establish equivalent, reduction, transposition, literal, and modulation. The authors used literal translation mostly, and it is done because the starting point of the imperative sentences are at the initial of the sentence and they are readable in the TL. The imperative is the starting of meaning for the source language and the target language. The readers are more acceptable to understand the context of the text. They are expected to implement the instructions in their daily lives.

Keywords: COVID-19, English, imperative sentences, Indonesian, translation techniques
\end{abstract}

Cite as: Sembiring, M., Risnawaty, R., Siregar, R., Arfanti, Y. \& Wuntu, C. N. (2021). Translating Imperative Sentences from English into Indonesian: COVID-19 Outbreak Text. Arab World English Journal for Translation \& Literary Studies 5 (4) 162-171. DOI: http://dx.doi.org/10.24093/awejtls/vol5no4.12

Arab World English Journal for Translation \& Literary Studies 


\section{Introduction}

An imperative is a structured rule, which consists of a base verb without to' gives orders, advice, requests, commands, or instructions for the readers or listeners. By understanding the messages of the imperative, the readers or listeners realize the benefits of the imperatives, and they follow the instruction.

The imperative sentences in Indonesian are divided into six groups, they are 1) command or order; 2) polite commands; 3) request;4) invitation and hope; 5) prohibition; and 6) omission. (Moeliono et al., 2017). Imperatives are used to tell or ask people what to do, to make suggestions, to give advice or instructions, to encourage and offer, or to express wishes for people's welfare ( Swan, 2003). Furthermore, Swan, (2003) explains that there are empathic imperative, passive imperative, subject with imperative, affirmative imperatives, negative imperatives in English.

The imperatives in this paper are collected from World Health Organization news, in 'Mental health and psychosocial considerations during the COVID-19 outbreak' text, (World Health Organization, 2020). It was delivered for the general population on 18 March 2020, and it is very crucial to implement in daily life. The general population should prioritize their health. WHO stated that there is a high risk of COVID-19 spreading to other countries around the world. (World Health Organization, 2020). This situation makes people throughout the world in a mental crisis. WHO delivers mental health and psychosocial considerations to overcome the COVID-19 pandemic. The readers should believe in WHO, and they know that the COVID-19 pandemic would be overcome. The mental health and psychosocial considerations should be translated into other languages to make the messages readable and acceptable.

In the process of translation, translators should be familiar with the translation theory they apply to get a close meaning of a source language (SL) in a target language (TL). Scholars have different kinds of translation theory, but they have the same goal, namely to transfer the messages of an SL into a TL. There are many translation methods proposed by (Newmark 1988), and they are supported by (Sembiring, Milisi. Panggabean, 2018).To know more about translating imperative, it is explained that the single imperative verb 'go' can be translated into six imperative verbs in Malay(Sulaiman \& Wilson, 2018).

In the process of translating the imperatives in the SL into the TL, the authors investigate the social context of the imperative sentence in the SL. Understanding the context situation in the SL is an effort to avoid misinterpretation of the imperative sentence itself.

The context of the situation is categorized as the field, tenor, and mode(Halliday \& Matthiessen, 2014).

\section{Literature Review}

House $(2018$, p. 9) defines translation is a procedure where an original text, often called 'the source text', is replaced by another text in a different language, often called the 'the target text'. The content and the language of the source text are transferred into the target text. The messages in the SL are analyzed before transferring into the TL. 
In the process of transferring the content of the source text into the target text, a translator should be able to apply a translation theory.

Molina and Albir (2002, pp. 510-511) adjust Vinay and Darbelnet's (1995) translation techniques, they propose eighteen translation techniques, they are as follows:

1) adaptation, 2) amplification, 3) borrowing, 4) calque,

5) compensation, 6) description, 7) discursive creation,

8) established equivalence, 9) generalization,

10) linguistic amplification, 11) linguistic compression,

12) literal translation, 13) modulation, 14) particularization, 15) reduction, 16) substitution 17)

transposition, and 18) variation.

The authors apply Molina and Albir's (2002) translation technique in translating the SL into the TL

\section{Method}

In translating the imperative sentences in the SL, the authors applied(Molina \& Albir's, 2002) translation techniques to have accurate meanings of the imperative sentences in the TL. Translation techniques allow us to describe the actual steps taken by the translators each other micro-unit and obtain clear data about the general methodological option chosen (Molina \& Albir, 2002).

\section{Data Analysis}

There are thirty-five messages for the general population (World Health Organization, 2020) that the authors have as the center of analysis in this paper. They translate twenty-three messages in English as the (SL) into Indonesian as the (TL), and all of them are in imperative sentences.

1. SL: Be empathetic to all those who are affected, in, and from any country.

TL: Berempatilah kepada semua orang yang terpapar pandemi "COVID-19, baik yang ada di dalam negeri maupun yang datang dari berbagai negara.

'Be empathetic' in example 1 of the SL is translated with berempatilah in the TL by using the transposition translation technique. Berempatilah is a verb in the process of affixation for the prefix- ber and the suffix -lah. The suffix -lah in the TL is to emphasize the verb in the imperative sentence. The word 'Be' has various meanings; it refers to a followed lexical category, and the authors translated it as "bersikap" as it describes the deed of 'empathetic.' 'Be empathetic' as an imperative refers to general people who are affected by COVID-19 from many countries, in many geographical locations. This imperative is used as advice (Jary \& Kissine, 2009), and advice is a function of imperative (Ingeish \& Hassan, 1985).

2. SL: Do not refer to people with the disease as "COVID-19 cases", "victims" "COVID-19 families" or "the diseased".

TL: Jangan memojokkan orang dengan kasus penyakit " COVID-19", keluarga "korban COVID-19" atau "orang yang terjangkit COVID-19".

Arab World English Journal for Translation \& Literary Studies 
Example 2 is the "negative imperative' where WHO gives prohibition to the general population not to blame one or other countries that are the source of the virus. The negative form of the imperative is just by putting do not before the infinitive verb in the SL. The meaning of this imperative sentence is a prohibition, is the same as the negative imperative,(Panai, 2019)

The authors apply the compensation translation technique to translate the prohibition in the SL into the TL.

3. SL: Minimize watching, reading, or listening to news about COVID-19 that causes you to feel anxious or distressed.

TL: Kurangilah menonton, membaca atau mendengarkan berita tentang COVID-19 yang membuat anda merasa kuatir atau tertekan.

The authors use established equivalent in translating the SL example 3 into the TL. The SL structure rule, for example, 3 , is the imperative followed by verb-ing, and it is different from the structure rule in the TL. The authors do not translate the word "minimize" to "minimalkan"; instead, the authors translate it to "kurangilah".

The literal translation technique is used to translate the SL into the TL, where the word or sentence is translated directly into the TL.

4. SL: Get the facts, not rumors and misinformation.

TL: Carilah fakta; bukan rumor dan infomasi yang keliru.

There is no subject when the imperative is used to give orders/commands, exclamations, and general instructions(Amaral et al., 2013). It is used to infinitive without to such as found in example 4. The imperative in the SL is translated literally, and the article 'the' in the SL is the omission in the TL.

5. SL: Gather information at regular intervals from the WHO website and local health authority platforms to help you distinguish facts from rumors.

TL: Kumpulkan informasi secara berkala dari situs WHO dan fasilitas otoritas kesehatan lokal untuk membantu anda membedakan fakta dari ketidakjelasan.

The imperative is followed by a noun in the SL and translated with the same structure rule in the TL. Gather information in the SL is translated literally with "kumpulkan informasi" in the TL.

6. SL: Seek information updates at specific times during the day, once or twice.

TL: Carilah informasi terkini pada waktu tertentu, satu kali atau dua kali sehari.

Example 4 is the "imperative instruction," which is translated literally. It is occupied by the context that WHO instructs the general population to seek information accurately and definitely to avoid misinterpretation. WHO suggests the general population to seek information not too much. 
AWEJ for Translation \& Literary Studies Volume, 5 Number 4. October 2021

7. SL: Protect yourself and be supportive to others.

TL: Lindungi dirimu dan dukung orang lain untuk mengikuti yang dianjurkan WHO.

The imperative, in the example, 7 , appears that the verb is followed by $2^{\text {nd }}$ person reflexives. It aims to advise for the common good. The modulation translation technique is used to translate the SL into the TL. The reflexive pronoun in the SL changed to be $2^{\text {nd }}$ person pronoun in the TL.

8. SL: Find opportunities to amplify positive and hopeful stories and positive images of local people who have experienced COVID-19.

TL: Cari peluang untuk memperkuat dukungan moril dan memberikan gambaran positif dari lngkungan setempat terhadap pasien yang telah pulih dari COVID-19.

The sentence above is categorized as the instruction, where WHO gave instruction and also the way to give a positive impact to the general population. The message of the SL is translated by modulation translation technique.

9. SL: Honour carers and healthcare workers supporting people affected with COVID-19 in your community.

TL: Hargailah petugas dan tenaga medis yang bertugas membantu orang yang terpapar COVID 19 di lingkungan anda.

The literal translation is applied in translating example 9 into the TL to have accurate meaning. It has no problem with this translation process.

10. SL:Avoid using unhelpful coping strategies such as the use of tobacco, alcohol, or other drugs.

TL:Hindari menggunakan coping strategies (strategi yang mengurangi stress) yang tidak bermanfaat seperti perokok, pemakai alkohol atau narkoba.

The use of the verb 'avoid' in the SL as the imperative followed by a verb-ing form in the SL. The words coping strategies in the SL should be borrowed in the TL, and it is explained with "strategi mengurangi stress". The use of tobacco in the SL is translated with "perokok" in the TL.

11. SL:Know how to provide support to people who are affected by COVID-19 and know how to link them with available resources.

TL:Ketahuilah bagaimana memberikan dukungan kepada orang yang terpapar COVID19 dan ketahuilah bagaimana menghubungkan mereka dengan tenaga medis yang ada.

The imperative, in example 11, "know how to provide' is like the instruction to the health workers who are on duty so that they can work well. The literal translation is used in transferring the message of the SL into the TL. The reduction appears in example 11, the use 'by' in the SL is omitted in the TL.

Arab World English Journal for Translation \& Literary Studies 
12. SL:Be sure to keep in mind that the current situation will not go away overnight and you should focus on longer-term occupational capacity rather than repeated short-term crisis responses.

TL:Yakinkan dirimu bahwa situasi ini tidak akan hilang dalam semalam dan anda harus lebih fokus pada pekerjaan di masa akan datang dari pada memikirkan apa yang sekarang ini..

This imperative shows the warning to all the staff; it showed by using words "be sure." It means this imperative must be realized or implemented. The modulation technique is used in the process of translating the SL into the TL.

13. SL:Manage urgent mental health and neurological complaints (e.g., delirium, psychosis, severe anxiety, or depression) within emergency or general healthcare facilities.

TL:Tanganilah masalah kesehatan mental dan neurologis yang serius (mis. Delirium, psikosis, kecemasan serius atau depresi) dalam fasilitas Instalasi Gawat Darurat atau Puskesmas.

The statement above reveals an order that the word "manage" is imperative, in example 13. The literal translation technique is applied in the translation process of example 13 into the TL to have an accurate meaning in the TL.

14. SL:Help children find positive ways to express feelings such as fear and sadness.

TL:Bantulah anak-anak dengan hal-hal yang positif untuk mengatasi rasa takut mereka terhadap COVID-19.

The word 'help' shows the imperative as a request, namely asking every parent to be positive to express their feeling. The authors apply the modulation translation technique to make them acceptable in the TL.

15. SL:Discuss COVID-19 with your children in an honest and age-appropriate way.

TL:Diskusikan COVID-19 dengan anak-anak anda dengan cara yang terbuka dan sesuai dengan usia mereka.

The word that shows imperative order is "discuss." This imperative gives orders from parents to their children to talk about COVID-19. The literal translation is used to translate the SL into the TL.

16. SL:Provide practical and emotional support through informal networks (families) and health professionals.

TL:Berikan dukungan yang praktis secara emosional melalui keluarga dan tenaga medis.

This statement is a form of imperative advice because the words show that we must give provide support to anyone to prevent stress that affects their health. This sentence is also translated 
using the equivalent technique because the words praktis dan emosional are taken from the source language that is practical and emotional.

17. SL:Engage family members and other support networks in providing information and helping people to practice prevention measures (e.g., handwashing, etc.).

TL:Libatkan anggota keluarga dan dukungan lainnya dalam memberikan informasi untuk membantu orang dalam tindakan pencegahan (mis. mencuci tangan, dll.).

This statement is a form of imperative advice. The words "make sure," are advisable imperative; the meaning of these words is like if we are in bad condition, make sure we have medicine for us to use it. The imperative advice is found in the SL, and it is translated literally.

18. SL:Be prepared and know in advance where how to get practical help if needed, like calling a taxi, having food delivered, and requesting medical care.

TL:Cari tahu bagaimana cara mendapatkan bantuan secara praktis jika diperlukan seperti memanggil taksi, mengantarkan makanan, dan meminta perawatan medis.

The sentence above is categorized as passive imperative, the words "be prepared", show instruction. The literal translation is used, Be prepared and know is translated into the TL as translated bersiaplah dan ketahui, changing the passive be prepared for the active cari tahu.

19. SL:Make sure you have up to two weeks of all your regular medicines that you may require. TL:Pastikan anda memiliki obat rutin hingga dua minggu yang mungkin anda perlukan.

The imperative sentence above is a kind of "warning imperative" where warning imperative to warn someone about something. showed by using the words "make sure." This imperative sentence is translated literally, which means to make sure something.

20. SL:Learn simple daily physical exercises to perform at home, in quarantine, or in isolation so you can maintain mobility and reduce boredom.

TL:Lakukan olahraga setiap hari di rumah, di karantina atau di tempat isolasi agar anda bisa menjaga stamina dan mengurangi kebosanan.

From the imperative sentence above, the sentence is the kind of "command," where the sentence "learn" showed the "command," which means to order someone to do something that can be marked by the use word "learn. It is translated literally.

21. SL:Keep in regular contact with loved ones (e.g., via telephone, e-mail, social media, or video conference).

TL:Tetap berhubungan secara teratur dengan orang yang dicintai (mis. via telepon, email, media sosial, atau video konferensi). 
The authors use literal translation to translate the imperative sentence, for example, 21. It is the " imperative command," which commands to keep in regular contact with loved ones.

22. SL:Stay connected and maintain your social networks.

Tetap mengikuti berita terkini dan terhubung dengan teman di media sosial. TL:

The imperative of example, 22, should be supported by the context of the situation. The word "stay" in the SL has an "advice" function for the readers. The agent of this imperative is WHO, which addresses the advice for the general population in the world. It advises you to stay connected and maintain your social networks. The authors apply a literal translation to transfer the SL into the TL.

23. SL:Exercise regularly, keep regular sleep routines, and eat healthy food.

TL:Olahraga secara teratur, tidur secara teratur dan makan makanan yang bergizi..

The authors translate the imperative, for example, 23 by literal translation technique.

\section{Findings and Discussion}

The authors focus on translating the imperative; on the other hand, it tells us about the context of the situation. The context of the imperatives in the SL delivered by WHO is as a suggestion, proposed advice, commands, or request, and general instructions. WHO suggests the general population prioritize their safety due to following the health protocol of the COVID-19 pandemic. The authors apply the translation techniques of (Molina \& Albir, 2002) to translate English imperatives into Indonesian. The translation technique is widely used by (Arafanti \& Asmarani, 2018), (Puspita Sari \& Ardi, 2013), (Zaim, 2017), (Đorđević, 2017). It is found that the literal translation technique is mostly used in the process of translation (Nurpermadi et al., 2020). The authors mostly use the literal translation technique in translating the SL into the TL.

\section{Conclusion}

All messages in the form of imperative sentences are prioritized for handling the COVID19 pandemic problem. The authors conclude that the literal translation technique is mostly applied to translate the imperative sentences in the "Mental Health and Considerations during the COVID19 " text. Reduction, established equivalent, transposition, and compensation are also used in translating the SL into the TL.

The imperative sentences in the SL are followed by a noun, verb-ing, past participle, adjective, and $2^{\text {nd }}$ person reflexive pronoun. Verbs infinitive without to is applied as the starting point of meaning in the imperatives sentences for both languages.

\footnotetext{
About the Authors

Dr. Milisi Sembiring is the Vice Dean for Academic Affairs of the Faculty of Letters. He is a Professor of Translation Studies at the Department of English Language and Literature, Universitas Methodist Indonesia, Medan. Dozens of his works have been published in various
}

Arab World English Journal for Translation \& Literary Studies 
international journals on Translating Karonese Culture into English.

ORCHID: https://orcid.org/0000-0002-3834-6897

Risnawaty currently works at Universitas Muslim Nusantara Al-Washliyah, Medan, Indonesia. Her qualification is Linguistics. She is the dean of the Faculty of English Literature and Teaching and Education. She is an associate professor at Universitas Muslim Nusantara Al-Washliyah, Medan,Indonesia. ORCHID: https://orcid.org/0000-0001-5439-7603

Roswani Siregar is an associate professor at the linguistics school translation section. She also teaches at Economic Faculty, Universitas Sumatera Utara and Universitas Al-Azhar Medan. Indonesia. ORCHID: https://orcid.org/0000-0002-7648-3016

Yulia Arfanti is an associate professor at the linguistics school translation section she also teaches at pascasarjana Universitas Muslim Nusantara Al-washliyah and as the translator at language center UMN ALWASHLIYAH Medan Indonesia.

ORCHID: https://orcid.org/0000-0003-1306-4145

Ceisy Nita Wuntu is one of the teaching staff at Manado State University Postgraduate Program. Her main interests are environmental literature, culture, and English language education. She is responsible for teaching courses in British and American Literature, Cross-Cultural Understanding, and Cross-Cultural Communication.

ORCHID: https://orcid.org/0000-0003-1773-9840

\section{References}

Amaral, G., Bushee, J., Cordani, U. G., KAWASHITA, K., Reynolds, J. H., ALMEIDA, F. F. M. D. E., de Almeida, F. F. M., Hasui, Y., de Brito Neves, B. B., Fuck, R. A., Oldenzaal, Z., Guida, A., Tchalenko, J. S., Peacock, D. C. P., Sanderson, D. J., Rotevatn, A., Nixon, C. W., Rotevatn, A., Sanderson, D. J., ... Junho, M. do C. B. (2013). No 主観的健康感老中 心とした在宅高齢者における 健康関連指標に関する共分散構造分析Title. Journal of Petrology, 369(1), 1689-1699. https://doi.org/10.1017/CBO9781107415324.004

Arafanti, M., \& Asmarani, R. (2018). the Translation Techniques Used in the Bilingual Destination Map "Peta Wisata Jawa Tengah" Translated Into "Central Java Tourist Map." ETERNAL (English Teaching Journal), 7(2), 1-12. https://doi.org/10.26877/eternal.v7i2.2163

Đorđević, J. (2017). Translation Techniques Revisited: the Applicability of Existing Solutions in Non-Literary Translation. Facta Universitatis, Series: Linguistics and Literature, 15, 035. https://doi.org/10.22190/full1702035d

Halliday, M. A. K., \& Matthiessen, C. M. I. M. (2014). Halliday's introduction to functional grammar: Fourth edition. Routledge.

House, J. (2018). Translation. Routledge.

Ingeish, B. K., \& Hassan, S. W. (1985). The Semantic Implications of the Imperatives in English and Arabic. 7(3), 15-29.

Jary, M., \& Kissine, M. (2009). Imperatives. In Imperatives. https://doi.org/10.1017/CBO9780511998126

Moeliono, Anton M., Lapoliwa. H., Alwi, H., Sangsaka, S.S.TJ.W., S. (2017). Tata Bahasa Baku 
Bahasa Indonesia (IV). Badan Pengembangan dan Pembinaan Bahasa, Kementerian Pendidikan dan Kebudayaan.

Molina, L., \& Albir, A. H. (2002). Translation techniques revisited: A dynamic and functionalist approach. Meta.

Newmark, P. (1988). A Textbook of Translation. Prentice HaH International vUIO Ltd.

Nurpermadi, E. D., Hartono, R., \& Sutopo, D. (2020). Translation Techniques and Quality of Indonesian-English Translation of Captions in Pekalongan Batik Museum. 10(4), 427436.

Panai, U. (2019). Uang Panai ". 4(3), 187-198. https://doi.org/10.30957/ijotl-tl.v4i3.609.An

Puspita Sari, W., \& Ardi, H. (2013). Translation Techniques and Translation Accuracy of English Translated Text of Tourism Brochure in Tanah Datar Regency. English Language and Literature E-Journal, September 2302-3546.

Sembiring, Milisi. Panggabean, H. (2018). Translating culture-bound terms in wedding speech texts of Karonese society into English. SKASE Journal of Translation and Interpretation, $11(1), 69-92$.

Sulaiman, M. Z., \& Wilson, R. (2018). Translating adventure tourism: From action to relaxation. GEMA Online Journal of Language Studies, 18(3), 1-16. https://doi.org/10.17576/gema2018-1803-01

Swan, M. (2002). Practical English usage (Second). Oxford University Press.

Vinay, J.-P., \& Darbelnet, J. (1995). Comparative Stylistics of French and English A methodology for translation. John Benjamins Publishing Company.

World Health Organization. (2020). Mental Health and Psychosocial Considerations During COVID-19 Outbreak. World Health Organization, January, 1-6.

Zaim, M. (2017). Implementing Scientific Approach to Teach English at Senior High School in Indonesia. Asian Social Science, 13(2), 33. https://doi.org/10.5539/ass.v13n2p33

Arab World English Journal for Translation \& Literary Studies 